---مجلة علوم الرافدين، المجلد 27، العدد 4 /عدد خاص بالمؤتمر العلمي الثالث لعلوم الحياة، ص 129-137، 2018----

استحثاث المقاومة ضد فايروس التقزم الثجيري للطماطة بالبايون واللرايبوفلافين

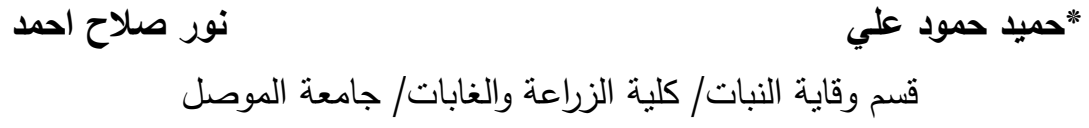

*E-mail: hameedkanoo@yahoo.com

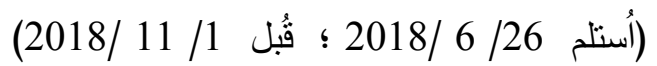

\title{
الملخص
}

هدفت هذه الدراسة الى تقييم كفاءة مستحضري البايون والراييوفلافين كعوامل استحثاث للمقاومة ضد فايروس التقزم الثجيري للطماطة في صنف الطماطة جيسي تحت ظروف البيت البلاسنيكي. وتضمنت التجربة معاملتين وهما، رش رهاء عوامل الاستحثاث على المجموع الخضري قبل وبعد 6،3 و 4،2 أيام من العدوى بالفايروس وبتركيزين 1ملغم و 2 ملغم /مل للبايون، 5 و 10 ملي مول/ مل للرايبوفلافين. قيمت المعاملات بوساطة مجموعة معايير تضمنت حساب النسبة المئوية للأصابة والتقييم المصلي بوساطة اختبار الاليزا وحساب التغيير في امتصاصية انزيم البيروكسيديز (POX) فضلا عن بعض معايير النمو • وحققت معاملة الرش بالبايون بتركيز 1ملغم/مل قبل ستة ايام من العدوى حماية عالية للنبات جراء العدوى اللاحقة بفايروس TBSV، إذ وصلت نسبة الاصابة الى 37,1 أسوة بمعاملة السيطرة. و بلغت اعلى نسبة منع تضاعف فايروس 7BSV T0 وذللك بعد الاسبوع الثالث من العدوى بعد معاملة رش البايون بتركيز 1 ملغم/مل قبل ستة ايام من العدوى وكان مقدار الامتصاص عند الطول الموجي 405 نانوميتر 0,296 نانوميتز قياساً بمعاملة السيطرة المعداة بالفيروس فقط والتي وصلت بالرايبوفلافين تركيز 10 ملي مول قبل العدوى بفايروس TBSV باربعة ايام اعلى نسبة في خفض نسبة المرض،فقد وصلت نسبة

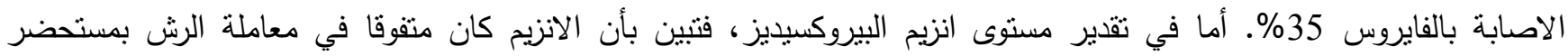

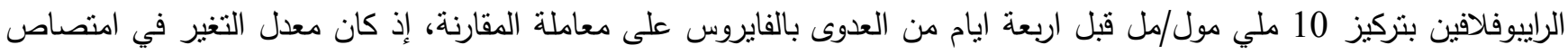
الضوء عند 420 نانومينز من نباتات الطماطة المعاملة 71.172 وذلك بعد 14 يوم من العدوى بالفايروس، مقارنة بمعاملة السيطرة

$$
\text { (فيروس + ماء مقطر ). }
$$

الكلمات الدالة: فايروس التقزم الثجيري للطماطة، استحثناث المقاومة، البايون، الرايبوفلافين.

\section{Induced of Systemic Resistance in Tomato Plant Against Tomato Bushy Stunt Virus by Bion and Riboflavin}

Hameed H. Ali

Department of Plant Protection/College of Agriculture and Forestry/ University of Mosul

\section{ABSTRACT}

The aim of this study was to evaluate the efficiency of abiotic agents Bion and Riboflavin in inducing resistance in tomato plant Geesy cultivar against Tomato bushy stunt virus (TBSV), under 


$$
\text { حميد حمود علي و نور صلاح احمد }
$$

plastic house conditions. The experiment was included two application with induce resistance agents: Bion \& Riboflavin used by two concentration for foliar spray before and after 3,6 and 2,4 days artificial inoculation with virus. The treatment was evaluated by using several parameters such as estimation of percentage and severity of disease infection, serological evaluation by DAS-ELISA, estimation of peroxidase absorbance change and some of the plant growth parameters. The best treatment was foliar spray with Bion $1 \mathrm{mg} / \mathrm{ml}$ before 6 days of virus inoculation showed reduction in the percentage of disease infection which was $37.1 \%$ compare with control treatment, on the other hand above treatment was caused high inhibition activity of virus (TBSV) multiplication which was $70 \%$ as demonstrated by ELISA absorbance values $0.296 \mathrm{~nm}$ compare with control treatment which inoculated with virus only was $0.972 \mathrm{~nm}$. Results also indicated that the treatment by spray Riboflavin concentration $10 \mathrm{mM}$ before (4 days) the inoculation of virus was inhibition of percentage of disease was 35\%. On the other hand the treatment was used of Riboflavin $10 \mathrm{mM}$ spray gave significant increase in the activity of peroxidase after 14 days of virus inoculation which was give 71.172 absorbance compare with control treatment which was 28.193.

Keywords: Tomato bushy stunt virus, Induce resistance, Bion, Riboflavin.

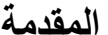

على الرغم من ان فكرة استحثاث المقاومة في النبات تبدو حديثة بعض الثيء إلا أنها في الحقيقة تعود الى عام 1901 عندما سجل Ray امكانية استحثاث المقاومة لمرض الصدأ بتلقيح النباتات بلقاح مهجن من المسبب المرضي لكن هذه الفكرة لم تحظ باهنمام المختصين بأمراض النباتات بسبب عدم امتلاك النبات لنظام مناعي كالموجود في اللبائن. وفي الحقيقة تمتلك النباتات آليات دفاعية

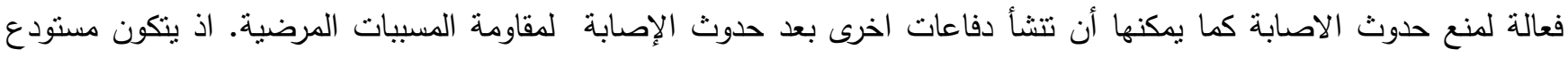
الدفاعات الكيميائية المستحدثة في النبات بشكل أساسي من مواد الأيض الثانوي التي من بينها الفايتو الكسينات أو ما تعرف بالدواحر والمركبات الفينولية التي نالت الجزء الأكبر من اهتمام المختصين في دراسة الأسس الأحياكيميائية لمقاومة النبات، كما يحوي مستودع

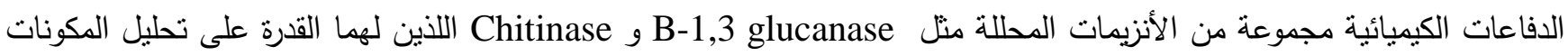
الأساسية للجدار الخلوي للفطريات (Abood, 1998). ويعد زيادة نشاط انزيم Phenyl alanine ammania-lyase) وأنزيم Peroxidase وما برافقها من زيادة في أيض المركبات الفينولية وبناء اللكنين ومن اهم الاسس الكيميائية لمقاومة النبات للمسببات المرضية. وخلال العقود الأخيرة شخص عدد من البروتينات ذات الوزن الجزيئي الواطئ من عوائل نباتية مختلفة ارتبط وجودها بحدوث الإصابة تدعى ببروتينات متعلقة بال إمراضية Pathogenesis-Related Proteins وهي تؤدي دوراً كبيراً في التعبير عن مقاومة النبات للمسببات المرضية. ومما لاثكك فيه بأن النباتات تمنلك مبكانيكيات منتوعة للدفاع عن نفسها ضد مهاجمة المسببات المرضية، وبعض هذه الميكانيكيات قابلة للتحفيز ـ وأكثر الأمتلة شيوعا في هذا الحقل هو تتشيط المقاومة في النبات عقب اصابته بمسبب مرضي

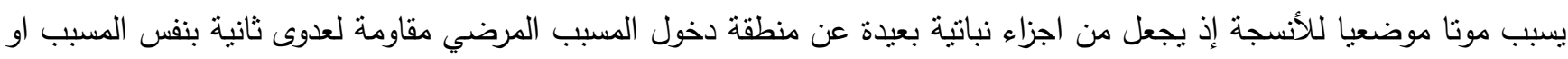
Systemic acquired resistance(SAR) مسببات اخرى مغايرة ويطلق على هذا النوع من المقاومة بالمقاومة الجهازية المكتسبة مونة وجزيئة الاشارة فيها اما جزيء دهون Lipids molecule أو حامض السالسليك Salicylic acid(SA) وينتج عنها تكوين بروتينات منعلقة بالامراضية، أما النوع الآخر من المقاومة تحدث في منطقة قريبة من منطقة الاستحثاث وتؤدي الى موت مفاجئ وسريع للخلايا 


\section{المواد وطرائق العمل}

\section{تقييم كفاءة تراكيز مختلفة من مركب البايون وفيتامين B2 في مقاومة فايروس التقزم الثجيري للطماطة}

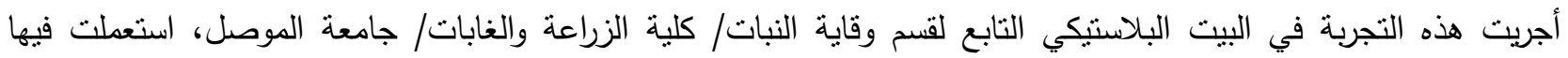
أُصص بلاستيكية بقطر 15 سم وارتفاع 25 سم، ولقد استعمل مركب البايون وفيتامين B2 بتركيزين لكل منهما رشاً على المجموع الخضري، وتم اضافة 250 مايكرو ليتر من مادة توين-20 الناشرة لكل تركيز من تراكيز المواد المستعملة (Tween -20)، ورُشت لتش

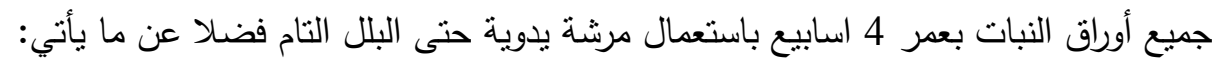
1- رش نباتات الطماطة بعمر شهر بمركب البايون بنركيز (1ملغم و2ملغم / مل) قبل 3 و6 يوم من العدوى وبعد 3 و6 يوم من بن العدوى بالفايروس وتضمنت التجربة 10 معاملات بالإضافة إلى معاملتي السبطرة الموجبة والسالبة 2- رش نباتات الطماطة بعمر شهر بمركب الرايبوفلافين بتركيز (5 ملي مول و 10 ملي مول ) قبل 2 و 4 من العدوى وبعد 2 و 4 يوم من العدوى بالفايروس وتضمنت التجربة 10 معاملة بالاضافة الى معاملتي السبطرة الموجبة والسالبة. نُفِّت التجربتين (1، 2) بأربعة مكررات واستخدم تصميم القطاعات العشوائية الكامل في تجارب البيت البلاسنتيكي وحللت النتائج باستخدام برنامجSAS الاصدار التاسع وقورنت المتوسطات باستخدام اختبار دنكن المتعدد المدى عند مستوى احتمال (0.05). وجرت متابعة الاعراض على النباتات المعاملة ومتابعة تضاعف الفايروس (تركيز الفايروس) في النباتات المعاملة باستعمال تقنية الاليزا ELISA ونم اعتماد قيم الامتصاصية في تقدير كفاءة مركبات الاستحثاث في مقاومة فايروس التقزم الثجيري للطماطة. تقييم معايير نمو المجموع الخضري: نم تقييم معايير نمو المجموع الخضري للنباتات المعاملة بمركب الاستحثاث البايون وذلك حسب اعب المعطيات الآتية: 1-ارتفاع النبات: تم قياس اطوال النباتات المعاملة بمركبات الاستحثاث، وهي ارتفاع المجموع الخضري بتأريخ 2014/5/25، بأخذ قياس النبات من القاعدة باتجاه القةة، بعد انتهاء التجربة، 2-عدد الافرع: تم حساب عدد الافرع للنباتات المعاملة على الساق الاساسي، 3- الوزن الطري: تم حساب الوزن الطري للمجموع الخضري والجذري، 4-الوزن الجاف: تم حساب الوزن الجاف للنباتات المعاملة بعد قلعها ووضعت في الفرن الكهربائي لمدة ثلاثة ايام وبدرجة 60 × سيليزية ، بعد وضعها في اكياس ورقية

تقدير فعالية انزيم البيروكسيديز Pexidase

اعتمدت طريقة الجراح (2011) في تقدير فعالية أنزيم البيروكسيديز وتلخصت هذه الطريقة بالأتي: 1- جُمعت عيناتٍ من أوراق الطماطة المعاملة بالرايبوفلافين (B2) حسب الجدول المذكور آنفاً وذللك بعد اسبوعين من آخر معاملة، وعُلمت ووضعت في اكياس من النايلون داخل مجمدة حوضية، بعدها غسلت الاوراق جيدا بالماء المقطر عدة مرات لإزالة الاتربة.

2- ت م اخذ 0.5 غم من اوراق العينات وقطعت الى قطع صغيرة، بعدها سحقت بوساطة مدقة داخل هاون خزفي وبوجود المحلول

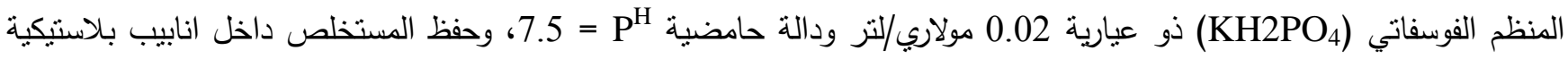
معقمة.

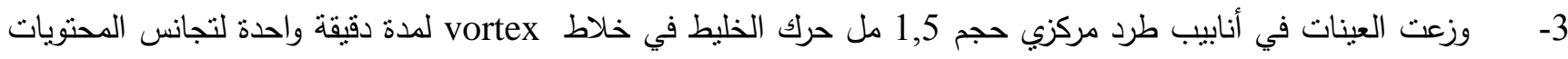
ثم عرضت لطرد مركزي بسرعة 6000 دورة /دقيقة ولمدة 5 دقائق. 
4- تم وضع 3مل من محلول التفاعل في انبوبة الـ Cuvette الخاصة بجهاز المطياف الضوئي Spectrophotometer، وتم اضافة 0.2 مل من الجزء الطافي للمستخلص النباتي المتحصل عليه من الخطوة رقم (3)، وقدر امتصاص العينة للضوء مباشرة بجهاز المطياف الضوئي من إنتاج شركة (Bioteh Engineering Management CO.Ltd. (UK)، وعلى طول موجي 420 نانوميتز كل 30 ثانية (تم اخذ ست قراءات)

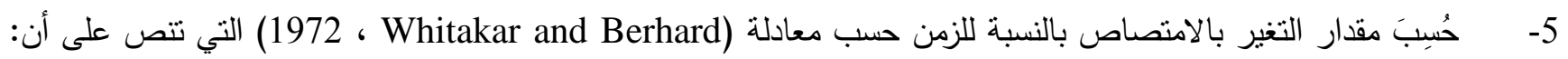
فعالية انزيم البيروكسيديز = مقدار التغير بالزمن Optical Density (O.D) $\Delta T$ مقدار التغير في الامتصاصية $=\Delta A$

\section{النتائج والمناقشة}

تقييم كفاءة مركب الاستحثاث البايون في فايروس التقزم الثجيري للطماطة ويعض معايير النمو لمحصول الطماطة

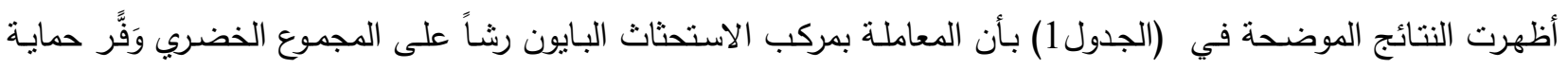

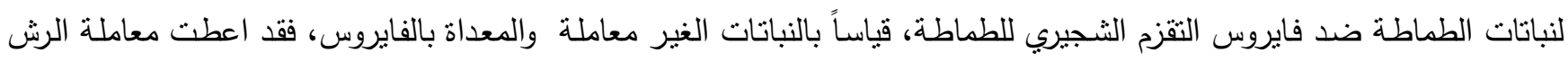
بمركب الاستحثاث البايون نركيز 1 ملغم/مل على نباتات الطماطة قبل ثلاثة ايام من العدوى خفض في نسبة الاصـابة التي بلغت

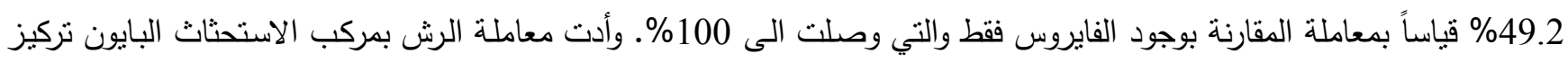

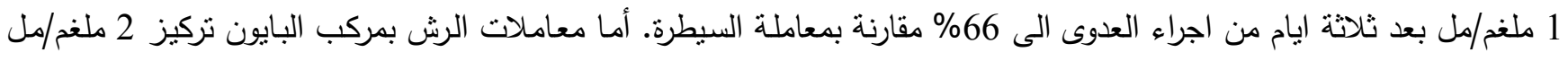

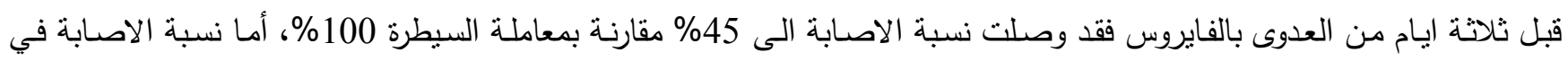

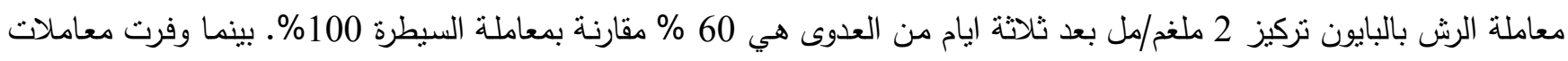
الرش بمركب البايون تركيز 1 ملغم/مل قبل ستة أيام من العدوى حماية للنبات جراء العدوى اللاحقة بالفايروس حيث أعطت افضل فئل

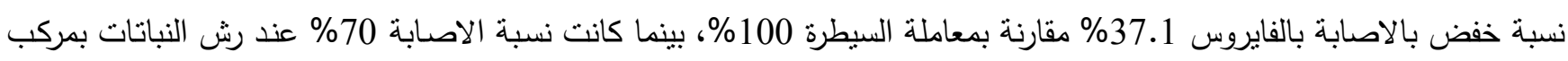

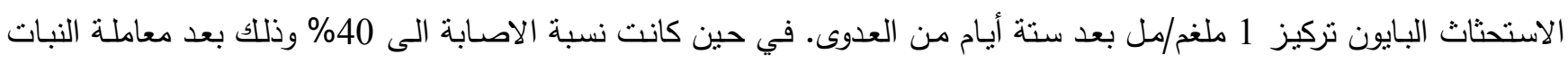

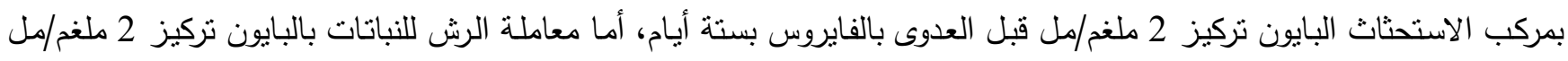

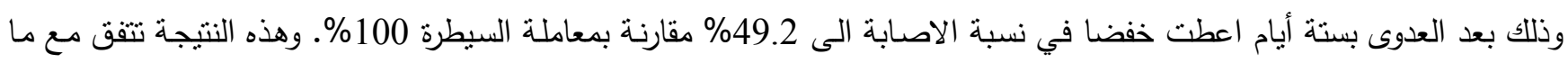
أنشار اليه (2000) من Pappu et al., من ان استعمال مركب الاستحثاث البايون رشّا على اوراق نباتات الطماطة وبتركيز 50 ملغم/لتر وتلقيحها بفايروس موزائيك الخيـار CMV بعد أول معاملـة سـواء في الحقل أو البيت الزجاجي، أدى الى خفض نسبة الإصـابة

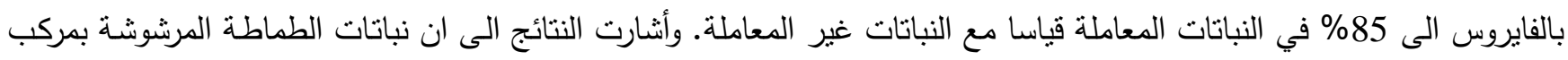
الاستحثاث البايون تركيز 1 ملغم/مل اعطت نتائج افضل من استعماله بتركيز 2 ملغم/مل في تخفيض نسبة الاصـابة بفايروس التقزم الثجيري، بينما وجد (1999) بshii et al. بأن معاملة نباتات الخيار بتراكيز واطئة من مركب الاستحثناث البايون وصلت الى 0.2

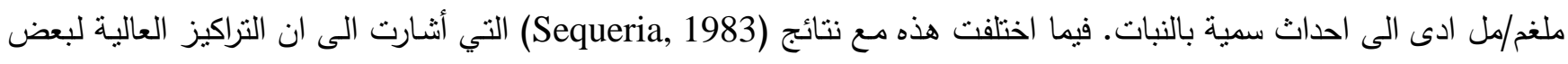

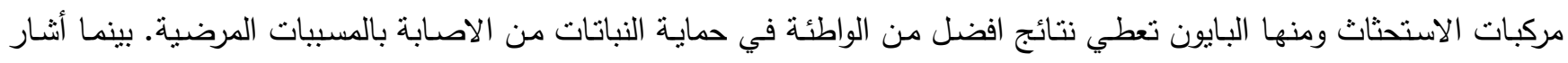

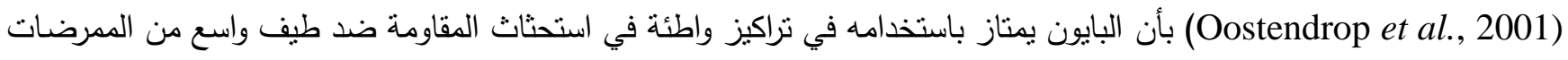
الفطرية والبكتيرية والفيروسية. ومن جانب آخر حققت معاملة الرش بمركب الاستحثاث البايون على المجموع الخضري تركيز 1 و 2 
ملغم/مل على المجموع الخضري لنباتات الطماطة دون التلقيح بالفايروس الى زيادة معنويـة في الوزن الطري والجاف، إذ بلغ الوزن الطري فيها 10 ، 9.5 غم/نبات على التتابع، في حين بلغ الوزن الجاف 3.8 ، 3.4 غم/ نبات قياساً بمعاملة السيطرة من دون وجود الفايروس فقد كان الوزن الطري 7.8 غم /نبات، أما الجاف فبلغ 2.5 غم /نبات. بينما أدت معاملة الرش بمركب الاستحثاث البايون تركيز 1 ملغم/مل قبل ثلاتثة أيام من العدوى بالفايروس وبعدها الى زيادة الوزن الطري بمقدار 6.8، 6.9 غم/نبات على التتابع، في بلفي حين وصل الوزن الجاف لنفس المعاملات 2.1 ، 2.2 غم/نبات على التتابع. وأثرت معاملة الرش بمركب الاستحثاث البايون تركيز 2 ملغم/ مل قبل ثلاثة ايام من العدوى بالفايروس وبعدها في زيادة الوزن الطري والجاف إذ بلغت 6.5 ، 6.3 ، 2 ، 1.9 غم /نبات على على 1.9 التوالي. ولم تختلف معاملات الرش بالبايون تركيز 1 ملغم/مل قبل ثلاتثة أيام من العدوى بالفايروس وبعدها معنوياً عن معاملات الرش باثل بالبايون نركيز 1 ملغم/مل قبل ستة أيام وبعدها، وكذلك الحال بالنسبة لمعاملات الرش بالبايون تركيز 2 ملغم/مل قبل ثنلاثة وستة أيام

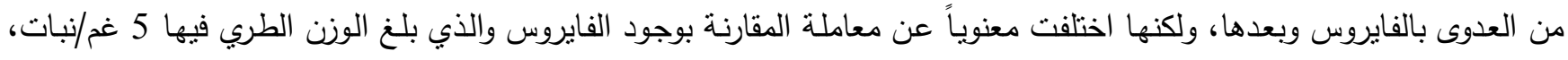
وبلغ الوزن الجاف 1.4 غم/نبات (الجدول 1). ويرجع دور فعالية مركب الاستحثاث البايون في زيادة معايير النمو الى قدرته في تحفيز

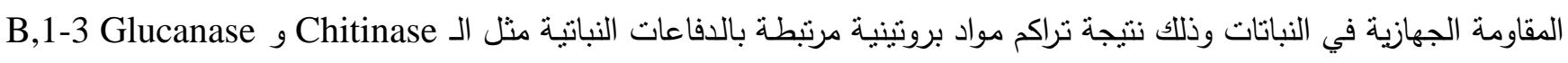

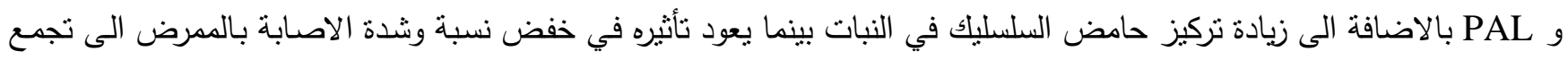
بيروكسيد الهيدروجين

.(Smith-Becker et al., 2003 ؛ Oostendrop et al., 2001)

تأثير عوامل الاستحثاث في منع تضاعف الفايروس

اشارت نتائج الاليزا إلى وجود تفاعل موجب منمثل باللون الاصفر في حفر اطباق الاليزا الحاوية على مستخلصات عينات

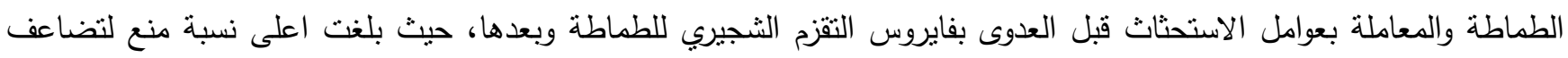

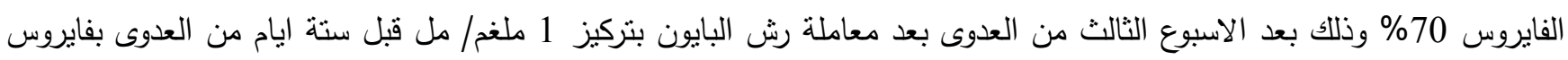
التقزم الثجيري للطماطة وكان مقدار الامتصاص Absorbance عند الطول الموجي 405 نانوميتر 0.290 (الجدول 2)، فياساً بمعاملة المقارنة المعداة بالفيروس فقط والتي وصلت الى 0.972 نانوميتز • بينما بلغت نسبة منع تضاعف فايروس فBSV في معاملة

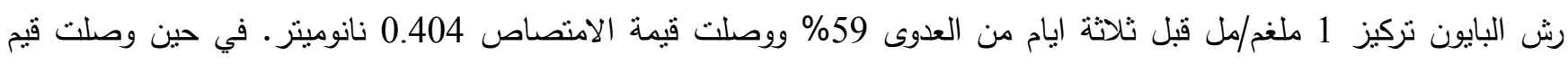
الامنصاص الموجي وذلك بعد رش البايون نركيز 1 ملغم/مل بعد ثناثة وستة ايام من العدوى بالفايروس 0.612 و 0.598 نانوميتز ونسبة منع تضاعف للفايروس بلغت 37\% و 39\% على التوالي، أما معاملات الرش بمركب البايون نركيز 2 ملغم /مل قبل ثناثة ايام من العدوى فقد ادت الى خفض في نسبة تضاعف الفايروس الى 62\% بينما وصلت قيمة الامتصاص الى 0.373 نانوميتز ، وكان

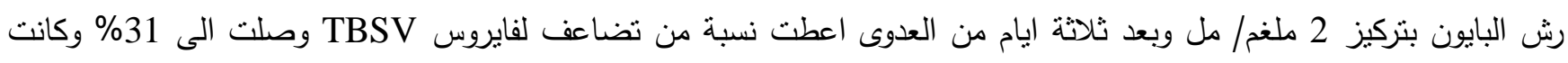

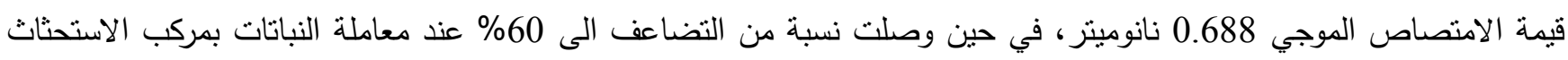
البايون رشاً بتركيز 2 ملغم/ مل قبل العدوى بستة ايام ووصلت قيمة الامتصاص 0.392 نانوميتر، بينما وصلت قيمة الامتصاص

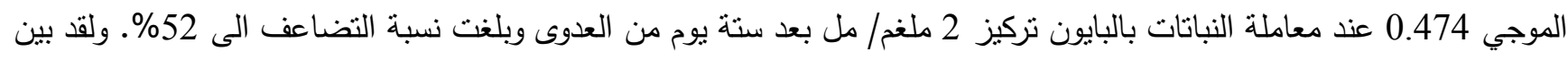

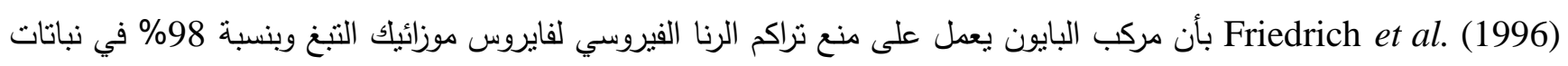

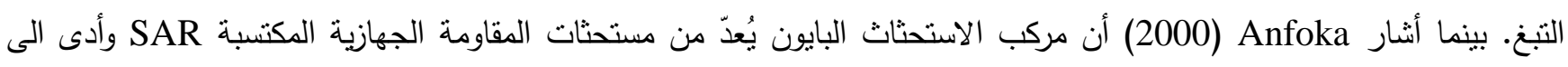

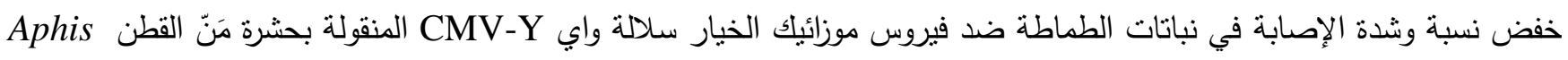




$$
\text { حميد حمود علي و نور صلاح احمد }
$$

gossypii إلى 12.5\%، وذللك عند معاملة نبات الطماطة بمركب البايون قبل سبعة أيام من التلقيح بالفايروس مقارنة بمعاملة النباتات

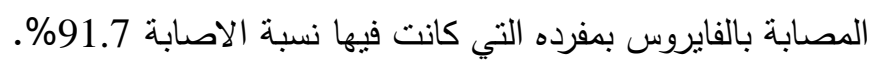




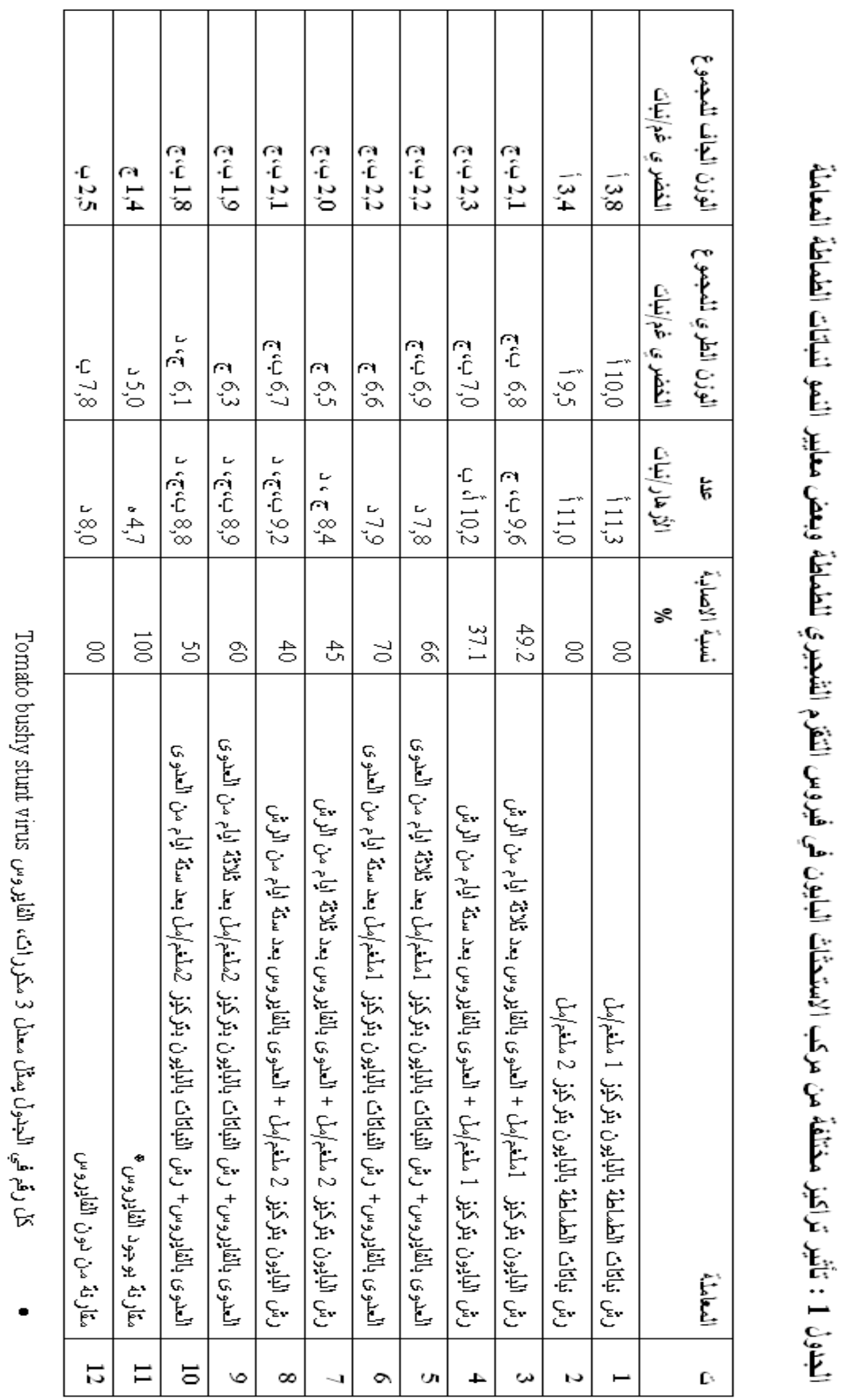


الجدول 2: تأثير مركب الاستحثاث البايون في النسبة المئوية لمنع تضاعف فايروس

\begin{tabular}{|c|c|c|}
\hline بعد 3 أسابيع من المعاصلي عند 405 نانوميتر & منع & 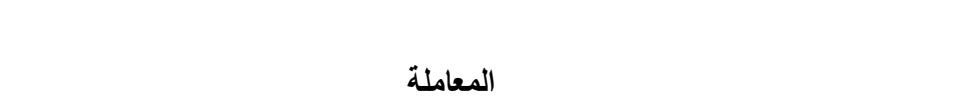 \\
\hline 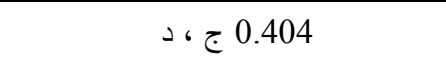 & 59 & رش نباتات الطماطة بالبايون بتركيز 1ملغم/مل ، ثم العدوى بالفايروس بعد 3 يوم \\
\hline 0.296 د & 70 & رش نباتات الطماطة بالبايون بتركيز 1ملغم/مل ، ثم العدوى بالفايروس بعد 6 يوم \\
\hline 0.612 & 37 & عدوى نباتات الطماطة بالفايروس، ثم رش النباتات بالبايون بتركيز 1 ملغم/مل بعد 3 يوم \\
\hline 0.598 & 39 & عدوى نباتات الطماطة بالفايروس، ثم رش النباتات بالبايون بتركيز 1 ملغم/مل بعد 6 يوم \\
\hline 0 0.373 ج ، د & 62 & رش نباتات الطماطة بالبايون بتركيز 2ملغم/مل ، ثم العدوى بالفايروس بعد 3 يوم \\
\hline 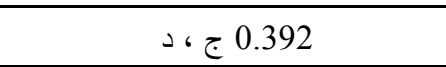 & 60 & رش نباتات الطماطة بالبايون بتركيز 2ملغم/مل ، ثم العدوى بالفايروس بعد 6 يوم \\
\hline 0.688 & 31 & عدوى نباتات الطماطة بالفايروس، ثم رش النباتات بالبايون بتركيز 2ملغم/مل بعد 3 يوم \\
\hline 0.474 & 52 & عدوى نباتات الطماطة بالفايروس، ثم رش النباتات بالبايون بتركيز 2ملغ/مل بعد 6 يوم \\
\hline 0.972 & 0.5 & مقارنة بوجود الفايروس \\
\hline 0.014 & 90 & مقارنة من دون الفايروس \\
\hline
\end{tabular}

كفاءة فيتامين B

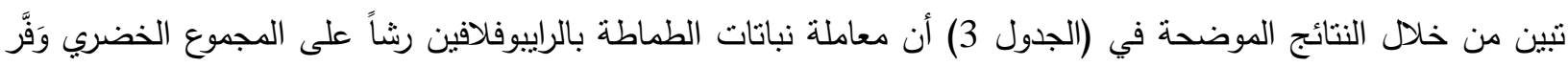
حماية لنباتات الطماطة ضد فيروس التقزم الثجيري للطماطة، قياساً بالنباتات غير المعاملة والمعداة بالفايروس، فقد اعطت معاملة الرش بالراييوفلافين تركيز 5 ملي مول/ مل على نباتات الطماطة فبل يومين من العدوى خفض في نسبة الاصابة وصلت الى 50\%

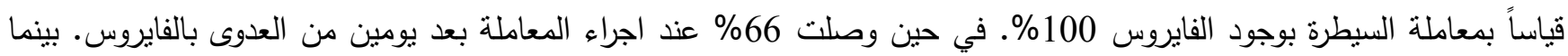

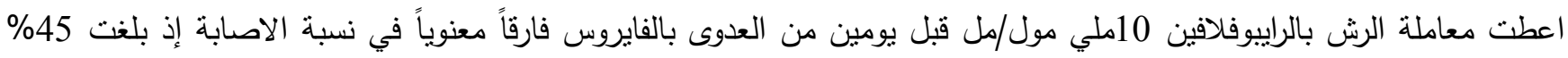
مقارنة بمعاملة السيطرة 100\%، في حين وصلت الى 67\% عند اجراء المعاملة بعد يومين من العدوى بالفايروس. وقد وفرت بـائ

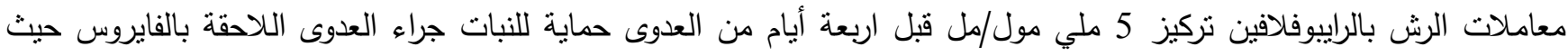

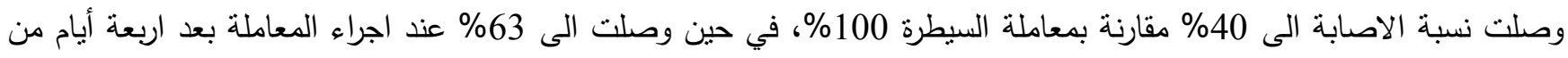
العدوى بالفايروس. في حين وصلت نسبة الاصابة الى 35\% وذلك بعد معاملة النبات بالرايبوفلافين تركيز 10 ملي مول/مل قبل

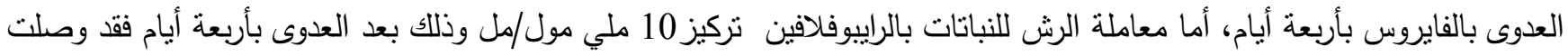
نسبة الاصابة الى 56\% وفي تقدير كفاءة فيتامين B2 راييوفلافين في استحثاثه للمقاومة في نباتات العنب ضد مسبب مرض البياض

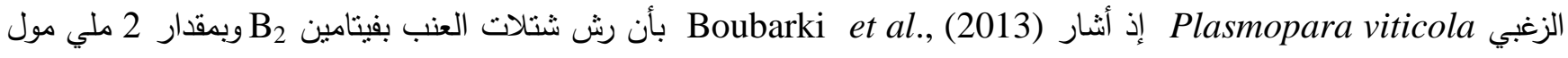
قبل ثلاثة ايام من تلقيحها بالمسبب المرضي قد خَفَض المرض بنسبة 86\% وأنشار (2010) .Azami-Sardooei et al بأن استعمال الرايبوفلافين B رشاً على اوراق نباتات الفاصوليا والطماطة قد أضاف مقاومة تلك النباتات للفطر Botrytis cinerea ، إذ خفض معدل انتشار البقع المتسبية عن الفطر B. cinerea بمقدار 25\% عند رش نباتات الفاصوليا بال مقارنة بالنبات غير المعاملة. وتم ملاحظة نراكم بيروكسيد الهيدروجين وتحفيز في نشاط انزيم Lipoxygenase في اقراص اوراق الفاصوليا المعاملة بال Bبكراً وذلك بعد اربع ساعات من التلقيح بالفطر المسبب. 
الجدول 3: فعالية أنزيم البيروكسيديز بعد اسبوعين من الاصابة بفايروس التقزم الثجيري للطماطة، في نباتات طماطة معاملة B2 بتراكيز مختلفة بالريبيوفلافين

\begin{tabular}{|c|c|c|}
\hline قيم امتصاص انزيم 420 نانوميتر بعد 14 عنX & $\begin{array}{c}\text { الاصابة } \\
\text { \% }\end{array}$ & 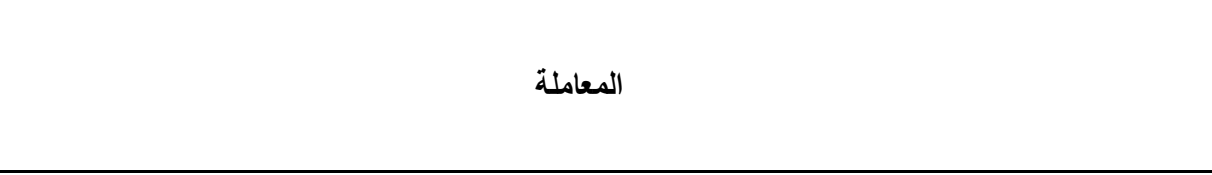 \\
\hline 43.210 & 50 & رش نباتات الطماطة بالراييوفلافين B2 بتركيز 5ملغ/مل ، ثم العدوى بالفايروس بعد 2 يوم من الرش \\
\hline 59.223 & 40 & رش نباتات الطماطة بالرايبوفلافين B2 بتركيز 5ملغ/مل ، ثم العدوى بالفايروس بعد 4 ايام من الرش \\
\hline و 34.238 & 66 & عدوى نباتات الطماطة بالفايروس، ثم ش النباتات بالرايبوفلافين B2 بنركيز 5ملغم/مل بعد2 يوم من العدوى \\
\hline 38.651 & 63 & عدوى نباتات الطماطة بالفايروس، ثم ش النباتات بالراييوفلافين B2 بتركيز 5ملغم/مل بعد 4 ايام من العدوى \\
\hline 51.034 & 45 & رش نباتات الطماطة بالرايبوفلافين B2 بتركيز 10ملغ/مل، ثم العدوى بالفايروس بعد 2 يوم من الرش \\
\hline 71.172 & 35 & رش نباتات الطماطة بالرايبوفلافين B2 بتركيز 10ملغم/مل، ثم العدوى بالفايروس بعد 4 ايام من الرش \\
\hline 33.491 & 67 & عدوى نباتات الطماطة بالفايروس، ثم ش النباتات بالرايبوفلافين B2 بتركيز 10ملغ/مل بعد 2 يوم من العدوى \\
\hline 41.091 & 56 & عدوى نباتات الطماطة بالفايروس، ثم ش النباتات بالرايبوفلافين B2 بتركيز 10ملغ/مل بعد 4 ايام من العدوى. \\
\hline j 28.193 & 100 & المقارنة (الفايروس فقط) \\
\hline
\end{tabular}

تقدير أنزيم البيروكسيديز: أظهرت نتائج تقدير فعالية انزيم البيروكسيديز في نباتات الطماطة المعاملة بالرايبوفلافين والمعداة بفايروس التقزم الثجيري للطماطة (الجدول 3) أنّ مستوى انزيم البيروكسيديز كان متفوقاً في معاملة الرش بمستحضر الراييوفلافين تركيز 10 ملي مول/مل وذللك قبل اربعة ايام من العدوى، على معاملة السيطرة، إذ كان معدل التغير في امتصاص الضوء عند 420 نانوميتز من نباتات الطماطة المعاملة 71.172 وذللك بعد 14 يوم من العدوى بالفايروس، في حين كان التغير في معاملة السيطرة (فايروس فقط+ ماء مقطر) 28.193. في حين وصل مقدار التغير في انزيم البيروكسيديز عند معاملة نباتات الطماطة بالرايبوفلافين بتركيز 5 ملي مول/مل قبل يومين واربعة ايام من العدوى وكذلك معاملة الرايبوفلافين تركيز 10 ملي مول/مل قبل يومين

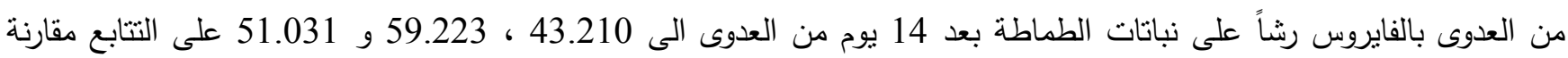
بمعاملة السيطرة. أما بالنسبة لمعاملات الرش بالراييوفلافين تركيز 5 ملي مول/مل بعد العدوى بيومين واربعة ايام فقد كانت فعالية انزيم البيروكسيديز في ادنى مستوياتها إذ وصلت 34.238 و 38.651 على التوالي وذلك بعد 14 يوم من آخر معاملة. في حين بلغ التغير

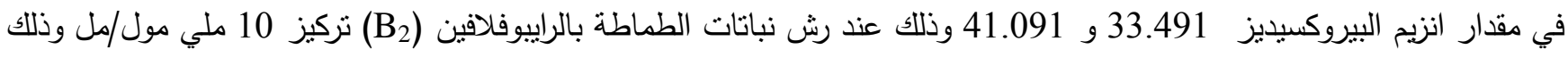

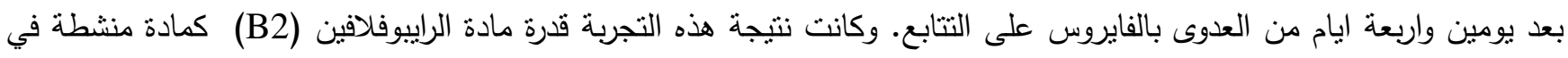
استحثاث البيروكسيديز داخل النباتات المعاملة به تعمل بتضاد مع المسببات الفايروسية الغازية لأنسجته، وكذلك انتاج مركبات دفاعية

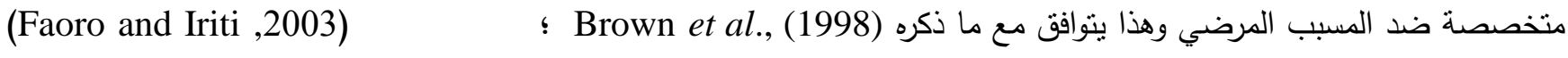
من دور هذه المنشطات في استحثاث المقاومة للنباتات ضد طيف واسع من المسببات المرضية، عن طريق آليات (ميكانيكيات) دفاعية 
مختلفة، مثل الانفجار التأكسدي Oxidative burst، أو عن طريق منتجات الأيض الثانوية. ومن هذه المواد أنزيم البيروكسيديز ، إذ يعتبر هذا الانزيم من البروتينات المرنبطة بالدفاع ويدعى VanStrien and VanLoon, 1999) PR-9). بينما ذكر ( Ride, (لئي 1975) بأن أنزيم البيروكسيديز بسهم في عملية تصنيع وترسيب اللكنين وبيروكسيد الهيدروجين التي بدورها تؤدي الى تقوية جدران الخلايا ضد غزو المسبب المرضي لها.

المصادر العربية

الجراح، نيران سالم احمد (2011). تأثثر الخليط الحيوي EM1 والمجال المغناطيسي في حماية نباتات الخيار من الاصابة بمسببات التعفن وسقوط البادرات. اطروحة دكتوراه. قسم وقاية النبات، كلية الزراعة والغابات، جامعة بغداد.

رمضان، نديم احمد ؛ قاسم، نبيل عزيز؛ البرزنجي، خالد احمد (2018). فايروس التبقع الحلقي التماوتي للأجاص، انتقاله بالبذور وحركته في انسجة اشجار اللوزيات. مجلة علوم الرافدين، 27 (2)، 1-11.

المصادر الأجنبية

Abood, H.M. (1998). Utilization of chitosan to induce systemic resistance to Fusarium wilt and root knot diseases in tomato. Ph. D. thesis, College of Agticulture, University of Baghdad.

Anfoka, GH. (2000). Benzo-(1,2,3)-thiadiazole-7-carbothioic acid S-methyl ester induces systemic resistance in tomato (Lycopersicon esculentum Mill. c.v Volledung) to cucumber mosaic virus. Cr. Pro. 19, 401-5.

Azami- Sardooei, Z.; Franca, S.C.; De Vleesschauwer, D.; Hofte, M. (2010). Riboflavin induces resistance against Botrytis cinerea in bean, by priming for a hydrogen peroxide- fueled resistance response. Physiol. and Mo. Plant Path. 75, 23-29.

Boubakri, H.; Chong, J.; Poutaraud, A.; Schmitt, C.; Bertsch, C.; Mliki, A.; Masson, J.E.; Soustse Gacougnolle, I. (2013). Riboflavin (vitamin B2) induces defence responses and resistance to Plasmopara viticola_in grapevine. Eu. J. Plant path. 136, 837-855.

Brown, I.; Trethowan, J.; Kerry, M.; Mansfield, J.; Bolwell, G.P. (1998). Localization of components of the oxidative cross-linking of glycoproteins and of callose synthesis in papillae formed during the interaction between non-pathogenic strains of Xanthomonas campestris and French bean mesophyll cells. Plant J. 15, 333-343.

Fridrich, L.K.; Ruess, W.; Masner, P.; Specker, N.; Gut-Rella, M. (1996). A benzothiadiazole derivative induces systemic acquired resistance in tobacco. Plant J., 10, 61-70.

Iriti, M.; Faoro, F. (2003). Benzothiadiazole (BTH) induces cell-death independent resistance in Phaseolus vulgaris against Uromyces appendiculatus. J. Phytopathol. 151, 171-180.

Ishii, H.; tomita, Y.; Horio, T.; Narusakay; Nakazawa, Y.; Nishimura, K.; Iwamoto, S. (1999). Induced resistance of acibenzolar-S-methyl (CGA 245704) to cucumber and Japanese pear disease. Eu. J. Plant Path. 105,77-85.

Oostendorp, M.; Kunz, W.; Dietrich, B.; Staub, T. (2001). Induced disease resistance in plants by chemicals. Eu. J. Plant Path. 107, 19-28.

Ride, J.P. (1975). Lighification in wounded wheat leaves in response to fungi and its Possible role in resistance. Physiol. Plant Pathol., 5, 125-134.

Pappu, H.R.; Csinos, A.S.; McPherson, R.M.; Jones, D.C.; Stephenson, M.G. (2000). Effect of acibenzolar-S-methyl and imidacloprid on suppression of tomato spotted wilt tospovirus in flue-cured tobacco. Cr. Prot., 19, 349-354.

Sequeira, L. (1983). Mechanisms of induced resistance in plants. Ann. Rev. Microbiol., 37, 51-79. 
Smith- Backer, J.; Keena, N.T.; Backer, J.O. (2003). Acibenzolar-s-methul induces resistance to Golletotrichum lagenatium and Gucumber mosaic virus in cantaloupe. Cr. Prot., 22, 769-774.

Vanloon, L.C.; Vanstrin, E.A. (1999). The families of pathogenesis related proteins, their activities, and comparative analysis of PR-1 type. Proteins, Physiol. and Mo. Plant Pathol., 55, 85-97. 